\title{
GEOGRAPHICAL NAMES IN THE WORLD
}

\section{(ADDRESS DELIVERED AT FIRST MILITARY NAMES CONGRESS HELD AT FORT KLAPPERKOP ON 30 OCTOBER 1992)}

\author{
Dr Peter E. Raper*
}

\section{INTRODUCTION}

A geographical name, sometimes also called a place name or toponym, is the name of any portion of the Earth that has a recognizable identity. Toponyms include the names of all natural and man-made features on and under the surface of the earth.

Since the time when people first started to communicate among themselves, the names they gave to features have played a very important role in their vocabulary. In recent times the use of geographical names has increased greatly because of the sophisticated communication technology and the great progress made in the media and printing.

Geographical names occur all over the world. They generally originate in a specific language, and are a part of the linguistic and cultural heritage of the people who speak that language. People tend to take pride in their geographical names, since these names reflect their history and their national character and image. Names are sensitive elements, and often when a country is invaded or colonized, or when there is a change in political power, names are among the first things to be changed.

Places may have more than one name, given by different language groups or by the same language group at different times. Conversely, more than one place may have the same name, for example Heidelberg in South Africa and in Germany. Amsterdam in Holland and in Transvaal, Wellington in New Zealand and in the Cape Province. A cursory glance at any list of names will show how many places there are with the same name.

Toponyms in any particular language are also used in other languages, and in other countries. So we speak of Am- sterdam, London, New York and Ottawa. Sometimes the names are adapted to a greater or lesser extent when used elsewhere, in pronunciation or spelling, for example Paris, Helsinki, Montreal. In many instances a completely different name may be given for a place from the one used locally, for example Leghorn for Livorno, Styria for Steiermark, Florence for Firenze, the Falklands for Islas Malvinas, Vienna for Wien, Geneva for Geneve. Such names are called exonyms.

Every language in the world has exonyms for places elsewhere. Geneva is Genf in German. Ginnevra in Italian. South Africa is variously known as Afrique du Sud, Etelä-Afrikka, Nanfei, Sudàfrika, Südafrika, and so forth. If, as has been estimated, there are 6000 languages in the world, each place could theoretically have 6000 different names.

When communication takes place at an international level, in maps and atlases, international timetables, trade agreements between nations, and so forth, the plethora of names can, and often does, give rise to misunderstanding. The situation is aggravated when non-Roman scripts are used, for example Arabic, Chinese, Greek, Hebrew, Japanese, and the like.

To summarize, then, the major problems appertaining to toponyms in the world are that there are more than one name for the same place, that there are variant spellings of toponyms, that there are exonyms in different languages, and that non-Roman scripts and systems are not readily understood by all.

Understandably the need for standardization has long existed at both national and international levels. In Canada, for example, the need was felt nearly a century ago to standardize 
the geographical names of that country. In South Africa we have had a body approving our place names for more than fifty years.

It is generally accepted that standardization signifies, as an ideal, that each place or entity should have only one name, and that that name should be written in only one way. It has already been shown that the reality in the world is very different. To bridge the gap between reality and ideal is the challenge of standardization.

\section{STATUS AND COMPOSITION OF THE UNGEGN}

To further the standardization of geographical names at both the national and international levels, the United $\mathrm{Na}$ tions Group of Experts on Geographical Names (UNGEGN) was established in pursuance of Economic and Social Council (ECOSOC) resolutions 715 A (XXVII) of 23 April 1959 and 1314 (LXIV) of 31 May 1968. The UNGEGN is one of the seven standing expert bodies of ECOSOC, and comprises experts from the member countries of the UN.

\section{GEOGRAPHICAL/LINGUISTIC DIVISIONS}

In terms of ECOSOC resolution 1314 (XLVI) of 31 May 1968 the UNGEGN is to provide for continuous co-ordination among countries to further the standardization of geographical na-mes. In order to achieve the required results, at both national and international levels, the UNGEGN performs its work by means of Divisions based on equitable geographic distribution and the different linguistic systems of the world. At present the following geographical/ linguistic divisions exist:

Africa Central Division:

Africa East Division;

Africa South Division:

Africa West Division;

Arabic Division:

Asia East Division (other than China);

Asia South-East and Pacific SouthWest Division;

Asia South-West Division (other than Arabic):

Baltic Division:
Celtic Division;

China Division:

Dutch- and German-speaking Division;

East Central and South-East Europe Division:

East Mediterranean Division (other than Arabic);

Eastern Europe, Northern and Central Asia Division:

India Division:

Latin America Division;

Norden Division;

Romano-Hellenic Division:

United Kingdom Division:

United States of America/Canada Division.

Each country is encouraged to participate in the activities of a Division, or of more than one Division, if desirable and appropriate. A country decides for itself to which Division(s) it wishes to belong, according to its geographical and/or linguistic affinities.

\section{WORKING GROUPS}

To deal with particular issues, working groups have been established within the UNGEGN, for example on

(a) Single Romanization system:

(b) Definitions:

(c) Names of undersea and mari time features;

(d) Training courses in toponymy;

(e) International gazetteers:

(f) Automated data processing:

(g) Extraterrestrial topographic names;

(h) Country names;

(i) Toponymic data files:

(j) Toponymic terminology:

(k) Implementation and evalua tion:

(I) Publicity and funding.

A working group is disbanded on completion of its appointed task.

\section{SESSIONS OF THE UNGEGN}

The UNGEGN meets at regular intervals (namely every two years, and in conjunction with the Conferences) and maintains communication between the members. The Chairman of the UNGEGN is responsible for reporting on its main activities to the United Nations, for liaising with the Secretariat to 
ensure continuity of work between sessions of the UNGEGN, etc.

\section{ACHIEVEMENTS OF THE UNGEGN}

\section{(i) Toponymic Guidelines}

The preparation of Toponymic Guidelines for Map and Other Editors is regarded as one of the major achievements of the UNGEGN.

These guidelines have been extremely well received by the international community. Each set of Guidelines includes, for a given country, the main facts, measures and achievements in the field of national standardization of geographical names, with reference i.a. to the legal status of names in the respective languages in multilingual countries; alphabet(s) of the language(s) and, where relevant, transliteration keys for non-Roman scripts; spelling rules, aids to pronunciation: glossary of generic and specific terms occurring in geographical names; source material; etc. Some 35 countries have already produced guidelines, most of them published in various United Nations publications. This project was spearheaded by Professor Josef Breu of Austria. He has been succeeded as co-ordinator of toponymic guidelines by Dr Peter E. Raper of South Africa.

\section{(ii) Toponymic Training Courses}

From the outset the need for toponymic training courses was emphasized. This project, initiated by Professor F.J. Ormeling (Snr.) of the Netherlands and now continued under the convenorship of his son, Professor F.J. Ormeling (Jnr.), has also been most successful. Training courses have been held in Cisarua (Indonesia), Rabat (Morocco), Quebec (Canada), Quito (Ecuador), Panama City (Panama), Cipanas (Indonesia) and, most recently, Pretoria (South Africa). The repeated recommendations by the UNGEGN and the relevant resolutions of the UN Conferences, to promote education and training in toponymy at the tertiary level, has stimulated the inclusion of this subject in the curricula of universities in Canada, Finland and Israel. The Survey of Southern African Geographical Names was also launched i.a. with a view to the implementation of these resolutions.

\section{(iii) Technical Terminology}

In collaboration with the UN Secretariat (Documentation, Refer ence and Terminology Section, Department of Conference Services) the Working Group on Terminology under the Convenorship of Mr H.A.G. Lewis (United Kingdom) published Glossary No. 330 , Technical Terminology Employed in the Standardization of Geographical Names. Containing 115 definitions and cross-references, with explanatory and descriptive information, in the six official languages of the United Nations, this glossary is now being revised by a Working Group under the Convenorship of Professor N. Kadmon of Israel.

\section{(iv) Romanization Systems}

Also notable are the achievement of the Working Group on Romanization Systems. For international purposes it was decided that the Roman alphabet should be employed in the standardization of geographical names. The implication of this decision is that for each non-Roman alphabet or script a single, romanization system, based on scientific principles, should be established according to which transliteration of geographical names can be effected. Under the convenorships of Messrs. De Silva (Mexico), Breu (Austria), Földi (Hungary) and Quinting (United States of America) transliteration keys were adopted for the conversion of Amharic, Chinese, Greek, Hebrew, and Russian Cyrillic.

\section{(v) Names Authorities}

When the UNGEGN was established, few countries in the world had names authorities. Today the need for standardizing bodies is recognized by all Governments and the establishment or strengthening of such authorities is receiving attention.

\section{UN CONFERENCES ON THE STANDARDIZATION OF GEOGRAPHICAL NAMES}

Apart from the UNGEGN, Governments are invited to participate in world-wide United Nations Conferences on the Standardization of Geographical Names which are held every five years. Observers from United Nations special- 
ized agencies, non-governmental organizations and international scientific agencies are also invited to these conferences. To date six Conferences have been held, namely in Geneva (1967), London (1972), Athens (1977), Geneva (1982), Montreal (1987) and New York (1992). The following Conference is scheduled to be held in Tehran, Iran, in 1997.

\section{GEOGRAPHICAL NAMES OF SOUTH AFRICA}

Since national standardization is accepted as the proper basis for international standardization, the importance of national standardization cannot be overemphasized. If we have trouble in coping with names of places elsewhere in the world, certainly our geographical names present difficulties to people and governments and cartographers elsewhere in the world. Since South Africa is a multilingual country, her geographical names derive from a multiplicity of languages. Although we have had a national geographical names authority for more than fifty years, not all of the problems associated with South African place names have been solved, even at the national level. I shall name a few.

The Taalkommissie of the S.A. Akademie vir Wetenskap en Kuns has approved four or five different ways of writing compounds in Afrikaans. The choice is left to the user of Afrikaans. Geographical names, however, are not language specific. Moreover, not only Afrikaans speaking people use geographical names, whether or not they originate in Afrikaans. Therefore the freedom of choice is not applicable when names are at issue. The National Place Names Committee has therefore determined that compound geographical names should be written as separate words in most cases. However, it has been decided that only new official names would be so written; names previously approved or standardized as one word will continue to be so written. On the other hand, a pertinent paragraph reads that names of natural features should be revised and written separately.

The problem now is this: how does one decide what is an existing official name and what is a new one (official means the name of a city or town or township, post office, railway station or motor bus stopping-place)? How does one know, especially if one is not a South African, whether Groot Brakrivier is the name of a river or a town, whether Rietfontein is a township or a spring, whether Brakpan is a town or a depression or both?

A further problem appertains to names from some of the indigenous African languages. Over the years different orthographic rules have been applicable, with the result that the same type of name, and even the same name. has been approved in different spellings, e.g. Umhlanga. Mngeni. Closely related is the question of names which were approved in a Europeanized form but which are felt by the mothertongue African-language speakers as insulting or at least insensitive, e.g. Umbogintwini.

If we as natives of the African sub-continent have difficulty in sorting these things out, how much more of a problem must it not be to people elsewhere in the world.

A last issue to be raised is that of univocity, and in our context specifically the lack of it. In our multilingual country names have been given by all sectors of the community. Often, perhaps much more often than is realized, the same place has been named in different languages. We know that Johannesburg is also known as Egoli and as Gauteng, that Pretoria is also known as Tshwane and Epitoli, Durban as Thekwini, Delportshoop as Dikgotlhong. and so forth. The alternative names are used daily, perhaps by more people than the officially approved ones.

If there were to be a change in the political dispensation in the country, many names approved in the past might be changed or superseded. It would be logical to expect that names already in widespread use for many years would be chosen to replace potentially offensive or hurtful names, names which were given and approved in a different political climate. The problem is that most of these names are as yet unknown to a large portion of the population, and of 
course in far greater measure to the international community.

\section{CONCLUSIVE REMARKS}

It was pointed out by Dr M.C. de Henseler, Consultant to the UNGEGN and former Secretary of the UNGEGN that most of the problems faced by the UNGEGN are not of a technical or substantive nature, but concentrated on surmounting administrative and communication problems.

I am not convinced that the same is the case in Southern Africa. There are seemingly incompatible demands by the orthographic rules of some of the indigenous languages on the one hand and the pragmatism of international names standardization on the other, for example the insistence on implementing syntactic rules even in contexts other than those of the language in question. This is one of the issues to be addressed at "grass-roots level by the Survey of Southern African Geographical Names.

A great deal of progress will be made by the implementation of relevant UN resolutions. Among the first issues to be addressed are the establishment of national names authorities in countries where they do not yet exist: the preparation and publication of adequate lists or gazetteers of geographical names, particularly for international use; the presentation of training courses in toponymy and the encouragement of toponymic education at the tertiary level; urgent attention to the sensitive issues of potentially offensive names and name-changes in a new political dispensation: the co-ordination of toponymic activities in Africa, as requested by the UN Economic Commission for Africa; the establishment of an extended UNGEGN Trust Fund and other fund-raising activities for the benefit of the sub-continent and specifically of the UNGEGN's Africa South Division; the operationalizing of the Survey, and so forth.

A topic which I have mentioned more than once is that of alternative place names. With a view to mutual understanding, the SADF Chapter of the Names Society of Southern Africa undertook a research project some time ago in co-operation with the HSRC to ascertain what these alternative names are and to publish them. The rapidly changing political scene has made this project one of the most urgent challenges. Fortunately both the SADF Chapter and the HSRC are participants in the Survey of Southern African Geographical Names. Other participants in the Survey will have to be involved in bringing this project to a speedy conclusion. In this way not only will the South African community be served, but the international community as well.

At a meeting of the Bureau of the Sixth UN Conference, the Director of the Science, Technology, Economic, Environment and Natural Resources Division of the UN Department of Economic and Social Development noted the possibility of the establishment of UN Centres at the request of Governments of countries. In such instances the costs are shared between the UN and the country concerned. The establishment of a United Nations Centre for Geographical Names, as requested by the assembly of the UN Toponymic Training Course held in Pretoria in June-July 1992, was mentioned as a possible joint venture. Negotiations to bring about the establishment of such a centre are envisaged between dignitaries of the UN, state departments, and other interested bodies.

I wish to thank the SADF Chapter of the NSA for the invaluable contribution it has made to names research in Southern Africa and the inititives it has taken in this regard. Continuing co-operation on this level will contribute to the implementation of UN resolutions and the success of toponymic activities.

\footnotetext{
* peter e. Raper Ph D (Human Science Research Centre (HSRC) Pretoria), is Chairman of the United Nations Group of Experts on Geographical Names (UNGEGN).
} 